\title{
Investigation of Viscosity's Effects on Continuous Casting of Steel Mold Powders Containing $\mathrm{B}_{2} \mathrm{O}_{3}, \mathrm{Li}_{2} \mathrm{O}, \mathrm{TiO}_{2}$, $\mathrm{Fe}_{2} \mathrm{O}_{3}, \mathrm{ZnO}$ and $\mathrm{Na}_{2} \mathrm{O}$
}

\author{
Ahmadreza Arefpour, Ahmad Monshi, Taghi Khayamian, Ali Saidi \\ Department of Materials Engineering, Najaf Abad Branch, Islamic Azad University, Isfahan, Iran \\ Email: arefpour.a@gmail.com
}

Received May 28, 2012; revised June 29, 2012; accepted July 11, 2012

\begin{abstract}
Mold powders are mainly formed of such oxides as $\mathrm{SiO}_{2}, \mathrm{CaO}, \mathrm{Al}_{2} \mathrm{O}_{3}, \mathrm{Na}_{2} \mathrm{O}$ along with $\mathrm{F}^{-}$and $\mathrm{C}$. One of the main constitutional composes of mold powders is $\mathrm{F}^{-}$, which is utilized in chemical composition of mold powders due to its features of controlling viscosity and producing desired lubrication between solidified steel shell and mold. However, the emission of $\mathrm{F}^{-}$through such compositions as HF (g) causes health and environmental problems. The purpose of this research is to decrease, and subsequently substitute, $\mathrm{F}^{-}$in chemical composition of a lubricating high speed powder, which is used in continuous casting of steel industry. A combination of $\mathrm{Fe}_{2} \mathrm{O}_{3}$ and $\mathrm{TiO}_{2}$ compositions to substitute $\mathrm{F}^{-}$in chemical composition of a fluorine-free mold powder was used to meet the purpose of this research. In addition, nine powder samples (A-I) with laboratory scale were prepared. In order to evaluate the samples' viscosity behavior, groove viscometer test and image analysis software was used and to evaluate the crystalline behavior of samples $C$ and G, XRD and SEM analyses were conducted. The results of these analyses demonstrated that the fluorine-free sample, due to its viscosity resemblance in comparison with molten reference powder and through creation of such crystalline phases as Perovskite $\left(\mathrm{CaTiO}_{3}\right)$ and Fayalite $\left(\mathrm{Fe}_{2} \mathrm{SiO}_{4}\right)$, will result in viscosity control of the mold powder and therefore optimizing continuous casting conditions. Finally, it is possible to derive that this sample may be an appropriate substitution for the reference powder being utilized in steel continuous casting industry.
\end{abstract}

Keywords: Mold Powder; Viscosity; Crystallization

\section{Introduction}

Mold powders are generally composed of such oxides as $\mathrm{SiO}_{2}, \mathrm{CaO}, \mathrm{Al}_{2} \mathrm{O}_{3}, \mathrm{Na}_{2} \mathrm{O}$ along with $\mathrm{F}^{-}$and $\mathrm{C}$ [1]. These powders that are mainly used in the continuous casting of steel slabs play a key role in the stability and improvement of the process and quality of the final surface of the product [2]. Some of the most important duties of mold powders include the protection of molten steel surface against oxidation, thermal insulation, lubrication, impurities absorption, heat transfer control between the steel shell and mold through solidified steel shell [3-5]. One of the major constituents of mold powders is fluorine $\left(\mathrm{CaF}_{2}\right)$, which is used to control viscosity and solidification temperature in the slag film through creation of crystalline sediment of Cuspidine $\left(3 \mathrm{CaO} \cdot 2 \mathrm{SiO}_{2} \cdot \mathrm{CaF}_{2}\right)[6$, 7]. These properties are directly related to lubrication and heat transfer between the steel shell and copper mold walls $[8,9]$. The diffusion of $\mathrm{F}^{-}$through such compounds as HF (g) causes health and environmental problems [10]. Regardless of safety and health aspects, the diffusion of $\mathrm{F}^{-}$can also bring about corrosion for the equipment used in continuous casting of steel by acidifying cooling waters $[11,12]$. In recent years, the diffusion of toxic substances from powders containing $\mathrm{F}^{-}$in cooling waters and its destructive effects on the environment have had the scientists to think of replacing $\mathrm{F}^{-}$with safer compounds [13]. Because of its special technical features, such as lower melting point, viscosity and the formation of crystalline particles, $\mathrm{F}^{-}$is utilized in the slag film [14, 15]. Therefore, any replacement of $\mathrm{CaF}_{2}$ must meet these objectives. The present study aims to change the chemical composition of a high speed lubricating powder, i.e. the reference powder in this research, used in continuous casting of steel industry. In other words, the aim of this study is to decrease $\mathrm{F}^{-}$in the chemical composition of the mold powder and replace it with other compositions, and subsequently study the effects of its replacements on viscosity. For that purpose, such compounds as iron oxide $\left(\mathrm{Fe}_{2} \mathrm{O}_{3}\right)$, titanium oxide $\left(\mathrm{TiO}_{2}\right)$, zinc oxide $(\mathrm{ZnO})$, sodium oxide $\left(\mathrm{Na}_{2} \mathrm{O}\right)$, boron oxide $\left(\mathrm{B}_{2} \mathrm{O}_{3}\right)$, lithium oxide $\left(\mathrm{Li}_{2} \mathrm{O}\right)$, were used as substitutes for fluorine $\left(\mathrm{CaF}_{2}\right)$ in the produced powders. Groove viscometer test as well as 
image analysis software studies were performed to compare the viscosity of the produced molten samples with that of the molten reference powder. In addition, in order to study the crystalline behavior of the reference powder, molten reference powder, sample C (low-fluorine sample), sample $G$ (fluorine-free sample), XRD and SEM analyses were prepared and reviewed. Finally, optimized compositions of samples $\mathrm{C}$ and $\mathrm{G}$ similar to the reference powder in terms of properties were introduced.

\section{Materials and Methods}

The high speed lubricating powder used in continuous casting of steel industry was named the "reference powder" in this research with its chemical composition shown in Table 1.

In order to prepare powder samples, mineral materials such as silica $\left(\mathrm{SiO}_{2}\right)$, sodium carbonate $\left(\mathrm{Na}_{2} \mathrm{CO}_{3}\right)$, manganese oxide $(\mathrm{MnO})$, magnesium oxide $(\mathrm{MgO})$, fluorine $\left(\mathrm{CaF}_{2}\right)$, iron oxide $\left(\mathrm{Fe}_{2} \mathrm{O}_{3}\right)$, zinc oxide $(\mathrm{ZnO})$, titanium oxide $\left(\mathrm{TiO}_{2}\right)$, boron oxide $\left(\mathrm{B}_{2} \mathrm{O}_{3}\right)$, lithium carbonate $\left(\mathrm{Li}_{2} \mathrm{CO}_{3}\right)$ and Portland cement clinker were used. The chemical composition of Portland cement clinker, which is free from harmful sulfated impurities, is shown in Table 2 .

In this research, the main purpose is evaluation of such compositions as $\mathrm{Fe}_{2} \mathrm{O}_{3}, \mathrm{TiO}_{2}, \mathrm{Na}_{2} \mathrm{O}, \mathrm{ZnO}, \mathrm{B}_{2} \mathrm{O}_{3}$ and $\mathrm{Li}_{2} \mathrm{O}$ upon mold powder viscosity. On the other hand, reference powder contains $\mathrm{C}_{\text {(total) }}$ which plays no role in controlling the viscosity of the mold powder, but rather influences the melting rate of it $[16,17]$. In order to determine the

Table 1. Chemical composition of the reference powder on the basis of weight percentage.

\begin{tabular}{cc}
\hline Chemical composition & Weight percentage \\
\hline $\mathrm{C}_{\text {(total) }}$ & $15-18$ \\
$\mathrm{C}_{\text {(free) }}$ & $7-9$ \\
$\mathrm{SiO}_{2}$ & $4.5-6.5$ \\
$\mathrm{Fe}_{2} \mathrm{O}_{3}$ & $28-29.5$ \\
$\mathrm{Al}_{2} \mathrm{O}_{3}$ & $1-2.5$ \\
$\mathrm{CaO}$ & $3-5$ \\
$\mathrm{MgO}$ & $26-28$ \\
$\mathrm{Na}_{2} \mathrm{O}+\mathrm{K}_{2} \mathrm{O}$ & $5-6$ \\
$\mathrm{MnO}$ & $6-8$ \\
$\mathrm{~F}^{-}$ & $4-6$ \\
$\mathrm{~S}$ & $3-4$ \\
$\mathrm{H}_{2} \mathrm{O}\left(120^{\circ} \mathrm{C}\right)$ & $<0.3$ \\
\hline
\end{tabular}

real effect of the viscosity and compare it in the molten reference powder with that of in the prepared samples, the reference powder was decarburized for 24 hours in $580^{\circ} \mathrm{C}$ [18]. The chemical composition of the decarburized reference powder achieved by XRF analysis is given in Table 3.

Based on the chemical composition of the reference powder (Table 1), the Portland cement clinker (Table 2), the decarburized reference powder (Table 3), and basicity of the reference powder $\left(\mathrm{CaO} / \mathrm{SiO}_{2}=0.94\right)$, nine powder samples were prepared. The chemical compositions of the samples are given in $\mathrm{wt} \%$ in Table 4.

In order to mix and homogenize the samples, they (50 gram of each sample) were placed with ethanol (the ethanol weighed the same as the powder) in the cups of a ball mill and were mixed with the ethanol there at 600

Table 2. Chemical analysis of Portland cement clinker in terms of weight percentage.

\begin{tabular}{cc}
\hline Chemical composition & Weight percentage \\
\hline $\mathrm{SiO}_{2}$ & 21.78 \\
$\mathrm{Al}_{2} \mathrm{O}_{3}$ & 5.41 \\
$\mathrm{Fe}_{2} \mathrm{O}_{3}$ & 3.14 \\
$\mathrm{CaO}$ & 64.32 \\
$\mathrm{MgO}$ & 1.89 \\
$\mathrm{~K}_{2} \mathrm{O}$ & 0.73 \\
$\mathrm{Na}_{2} \mathrm{O}$ & 0.28 \\
$\mathrm{SO}_{3}$ & 0.01 \\
\hline
\end{tabular}

Table 3. XRF analysis result of chemical composition of decarburized reference powder.

\begin{tabular}{cc}
\hline Chemical composition & Weight percentage \\
\hline $\mathrm{CaO}$ & 35.99 \\
$\mathrm{SiO}_{2}$ & 31.06 \\
$\mathrm{Na}_{2} \mathrm{O}$ & 8.78 \\
$\mathrm{MnO}$ & 5.95 \\
$\mathrm{Al}_{2} \mathrm{O}_{3}$ & 5.59 \\
$\mathrm{MgO}^{-}$ & 5.58 \\
$\mathrm{~F}^{-}$ & 4.50 \\
$\mathrm{Fe}_{2} \mathrm{O}_{3}$ & 2.67 \\
$\mathrm{SO}_{3}$ & 0.387 \\
$\mathrm{TiO}_{2}$ & 0.275 \\
$\mathrm{~K}_{2} \mathrm{O}$ & 0.199 \\
$\mathrm{LOI}^{*}$ & 0.63 \\
\hline
\end{tabular}


Table 4. Chemical analysis of prepared samples based on weight percentage.

\begin{tabular}{|c|c|c|c|c|c|c|c|c|c|c|c|c|c|c|c|}
\hline & $\mathrm{CaO}$ & $\mathrm{SiO}_{2}$ & $\mathrm{Al}_{2} \mathrm{O}_{3}$ & $\mathrm{Fe}_{2} \mathrm{O}_{3}$ & $\mathrm{MnO}$ & $\mathrm{MgO}$ & $\mathrm{Na}_{2} \mathrm{O}$ & $\mathrm{F}^{-}$ & $\mathrm{K}_{2} \mathrm{O}$ & $\mathrm{TiO}_{2}$ & $\mathrm{ZnO}$ & $\mathrm{C}$ & $\mathrm{S}$ & $\mathrm{B}_{2} \mathrm{O}_{3}$ & $\mathrm{Li}_{2} \mathrm{O}$ \\
\hline $\mathbf{A}$ & 34.34 & 33.2 & 2.62 & 1.52 & 6.32 & 5.93 & 9.17 & 2.13 & 0.35 & & & 1.74 & 0.004 & 2.66 & \\
\hline B & 33.98 & 32.85 & 2.6 & 1.5 & 6.26 & 5.387 & 9.08 & 2.1 & 0.35 & & & 2.378 & 0.004 & & 2.63 \\
\hline C & 33.11 & 32.01 & 2.53 & 1.46 & 6.1 & 5.72 & 8.84 & 2.05 & 0.34 & 6.15 & & 1.7 & 0.004 & & \\
\hline D & 34.52 & 33.38 & 2.64 & 1.53 & 6.36 & 5.96 & 9.2 & 2.14 & 0.35 & & & 1.75 & 0.004 & 2.14 & \\
\hline $\mathbf{E}$ & 33.5 & 33.9 & 2.7 & 1.55 & 6.5 & 6.06 & 9.37 & 1.08 & 0.36 & & & 1.8 & 0.004 & 3.26 & \\
\hline $\mathbf{F}$ & 32.4 & 34.46 & 2.72 & 1.6 & 6.56 & 6.16 & 9.52 & & 0.36 & & & 1.81 & 0.004 & 4.4 & \\
\hline G & 31.7 & 33.7 & 2.67 & 4.78 & 6.42 & 6.02 & 9.32 & & 0.36 & 3.24 & & 1.77 & 0.004 & & \\
\hline H & 32.4 & 34.5 & 2.72 & 1.6 & 6.56 & 6.16 & 9.52 & & 0.36 & 3.30 & 1.1 & 1.81 & 0.004 & & \\
\hline I & 32.55 & 34.62 & 2.74 & 1.6 & 6.6 & 6.2 & 10.07 & & 0.36 & 3.33 & & 1.95 & 0.004 & & \\
\hline
\end{tabular}

Rpm for 5 minutes. Then, in order for the ethanol to evaporate and the powders to dry, the samples were placed in a dryer at $110^{\circ} \mathrm{C}$ for three hours. After that, tablets weighing 1 gram, measuring $13 \mathrm{~mm}$ in thickness and $2 \mathrm{~mm}$ in height were prepared from the dried samples and the reference powder using a press machine with a pressure of $6 \mathrm{MT}$. Thereafter, the tablets were placed on top of a groove viscometer and the viscometer was put on a slope at $45^{\circ}$ and the whole thing was placed inside the furnace. The furnace was heated to $1150^{\circ} \mathrm{C}$. At that temperature, the samples melted on the grooves of the groove viscometer. Finally, the furnace was turned off and the whole thing was left to cool off inside the furnace. In order to further compare the viscosity of the produced samples with that of the molten reference powder, an image analysis software was used, which calculated the surface areas of the molten samples on the viscometer grooves in an approximate manner.

\section{Results and Discussion}

\subsection{The Effect of Viscosity on Samples}

Before a review of the results and discussion, it is worth mentioning that the reference powder was melted at $1150^{\circ} \mathrm{C}$. This sample was named "molten reference powder", in this research and its lubrication was compared to those of the lab samples. The amount of $\mathrm{F}^{-}$in the reference powder is about $3-4 \mathrm{wt} \%$. This is equivalent to about $6-8 \mathrm{wt} \% \mathrm{CaF}_{2}$. What is shown in Figure 1 as sample A contains $2.13 \mathrm{wt} \%$ of $\mathrm{F}^{-}$and $2.66 \mathrm{wt} \%$ of $\mathrm{B}_{2} \mathrm{O}_{3}$.

It was observed that $\mathrm{B}_{2} \mathrm{O}_{3}$ along with $\mathrm{CaF}_{2}$ produced too much fluidity and the viscosity of this sample is not similar to that of the molten reference powder. In other words, it can be said that $\mathrm{B}_{2} \mathrm{O}_{3}$ is a potent lubricating oxide with more fluidity than $\mathrm{CaF}_{2}$. It can be concluded that in sample $A$, the combination of $\mathrm{B}_{2} \mathrm{O}_{3}$ along with
$\mathrm{CaF}_{2}$ is not a suitable one for the mold powder. Therefore, comparing the viscosity of sample A with that of the molten reference powder, it can be generally concluded that sample A has not controlled viscosity as opposed to the molten reference powder since it has attained much lower viscosity than the latter. In sample $\mathrm{B}$, by reducing to $\mathrm{CaF}_{2}$ and adding $2.63 \mathrm{wt} \%$ of $\mathrm{Li}_{2} \mathrm{O}$, it was observed that $\mathrm{Li}_{2} \mathrm{O}$ along with $\mathrm{CaF}_{2}$ produced much more fluidity than sample $\mathrm{A}$ in the mold powder. It can be concluded that $\mathrm{Li}_{2} \mathrm{O}$ is more lubricating than both $\mathrm{B}_{2} \mathrm{O}_{3}$ and $\mathrm{CaF}_{2}$. Sample $\mathrm{C}$, which contains $6.15 \mathrm{wt} \%$ of $\mathrm{TiO}_{2}$ and 2.05 $\mathrm{wt} \%$ of $\mathrm{F}^{-}$, was able to reduce the amount of fluidity in comparison to $\mathrm{B}_{2} \mathrm{O}_{3}$ and $\mathrm{Li}_{2} \mathrm{O}$, and it had similar viscosity to that of the molten reference powder. Thus, it is useful to have $\mathrm{TiO}_{2}$ in the mold powder synthesis because $\mathrm{TiO}_{2}$ nucleates in powder and generates some phases such as Cuspidine. In other words, Provskite $\left(\mathrm{CaTiO}_{3}\right)$, i.e. crystalline sediment similar to Cuspidine, was attained by adding the right amount of $\mathrm{TiO}_{2}$ to sample C. Provskite in sample $\mathrm{C}$ has a function similar to Cuspidine having resulted in similar properties to those of the molten reference powder. The amount of the $\mathrm{F}^{-}$ was decreased ranging from 51 to $68 \mathrm{wt} \%$. By referring

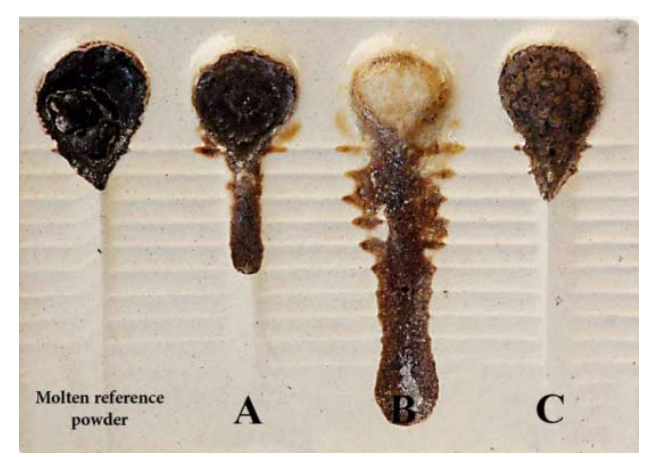

Figure 1. A schematic of the viscometer of molten samples $A, B$ and $C$ in comparison to the molten reference powder. 
to Figure 1 and our discussions, it can be said that $\mathrm{Li}_{2} \mathrm{O}$, compared to $\mathrm{B}_{2} \mathrm{O}_{3}$, produces more fluidity, and $\mathrm{B}_{2} \mathrm{O}_{3}$ also produces more fluidity than $\mathrm{TiO}_{2}$. There is a relation as the following among these three oxides regarding fluidity:

$$
\mathrm{Li}_{2} \mathrm{O}>\mathrm{B}_{2} \mathrm{O}_{3}>\mathrm{TiO}_{2}
$$

Table 5 shows an approximate calculation of the surface areas of samples A, B and C as well as the molten reference powder.

Sample A has an approximate surface area of 421.083, sample B, 530.593, and sample C, $325.680 \mathrm{~mm}^{2}$ gained from the approximate surface area of the molten reference powder, i.e. $346.448 \mathrm{~mm}^{2}$. As a result, sample C gained a similar lubrication to that of the molten reference powder. In the next step, the effects of $\mathrm{B}_{2} \mathrm{O}_{3}$ on the lubrication of low-fluorine samples, i.e. $\mathrm{D}$ and $\mathrm{E}$, as well as on fluorine-free sample, $\mathrm{F}$ were studied. In this group of samples, $\mathrm{B}_{2} \mathrm{O}_{3}$ was used as a substitution to decrease $\mathrm{CaF}_{2}$. Sample D contains $2.14 \mathrm{wt} \%$ of $\mathrm{F}^{-}$and $2.14 \mathrm{wt} \%$ of $\mathrm{B}_{2} \mathrm{O}_{3}$. This sample increased lubrication compared to the molten reference powder. Sample E contains 1.08 $\mathrm{wt} \%$ of $\mathrm{F}^{-}$and $3.26 \mathrm{wt} \%$ of $\mathrm{B}_{2} \mathrm{O}_{3}$. Similar to sample $\mathrm{D}$, this sample also increased lubrication compared to the molten reference powder. As shown in Figure 2, the protrusion of the melt from the grooves of the viscometer in samples D and $\mathrm{E}$ was due to an expansion of lubrication. Sample $\mathrm{F}$ did not include $\mathrm{CaF}_{2}$, but rather contained 4.4 $\mathrm{wt} \%$ of $\mathrm{B}_{2} \mathrm{O}_{3}$.

With the increase of $\mathrm{B}_{2} \mathrm{O}_{3}$, the viscosity of this sample increased compared to that of the molten reference powder. It seems that $\mathrm{B}_{2} \mathrm{O}_{3}$ in amounts between 2 to $4.4 \mathrm{wt} \%$ causes more lubrication in comparison to the molten

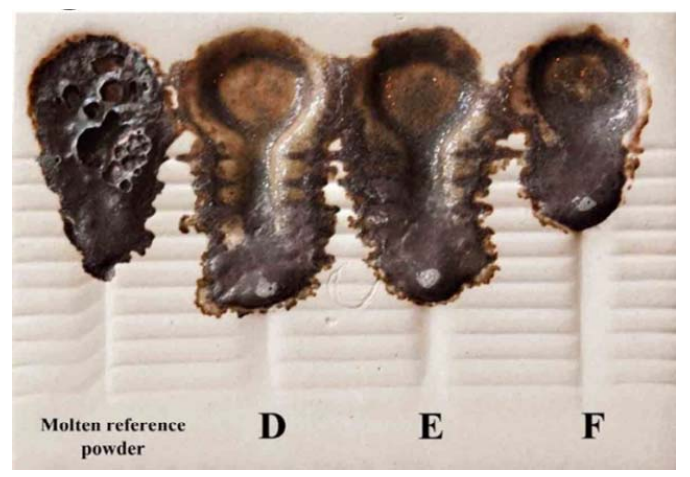

Figure 2. A schematic of the viscometer of molten samples $D, E$ and $F$ in comparison to the molten reference powder.

Table 5. Approximate surface area of samples A, B, C and molten reference powder $\left(\mathrm{mm}^{2}\right)$.

\begin{tabular}{ccccc}
\hline Sample name & $\begin{array}{c}\text { Molten reference } \\
\text { powder }\end{array}$ & A & B & C \\
\hline $\begin{array}{c}\text { Approximate } \\
\text { surface area }\left(\mathrm{mm}^{2}\right)\end{array}$ & 346.448 & 421.083 & 530.593 & 325.680 \\
\hline
\end{tabular}

reference powder. It seems that less amounts than $2 \mathrm{wt} \%$ of $\mathrm{B}_{2} \mathrm{O}_{3}$ would result in comparable lubrication with that of the molten reference powder. Finally, using $\mathrm{B}_{2} \mathrm{O}_{3}$ in more amounts than $4.4 \mathrm{wt} \%$ would apparently decrease mold powder lubrication in an unfavorable way. Table 6 shows an approximate calculation of the surface areas of samples D, E and F as well as the molten reference powder.

The first three samples, D, E, and F, have approximate surface areas of $967.155,983.564$ and, $584.646 \mathrm{~mm}^{2}$ respectively, and molten reference powder with the approximate surface area of $723.002 \mathrm{~mm}^{2}$. A comparison of the surface areas shows that none of these samples had a similar lubrication to that of the molten reference powder. $\mathrm{CaF}_{2}$ was completely omitted from the chemical composition of samples $\mathrm{G}, \mathrm{H}$ and I. In sample $\mathrm{G}$ (Figure 3) $\mathrm{Fe}_{2} \mathrm{O}_{3}$ was increased from $1.54 \mathrm{wt} \%$ to $4.78 \mathrm{wt} \% .3 .24$ $\mathrm{wt} \%$ of $\mathrm{TiO}_{2}$ was also added to sample $\mathrm{G}$.

As seen in Figure 3, sample $G$ is a fluorine-free sample with similar viscosity to that of the molten reference powder. In sample $\mathrm{G}, \mathrm{TiO}_{2}$ seems to have acted as an embryo maker in this sample. On the other hand, there is a potent bond breaking compound called $\mathrm{Fe}_{2} \mathrm{O}_{3}$ in this sample, which reduces mold powder viscosity through bond breaking in the silicate network by breaking bridge oxygen into non-pole ones. $\mathrm{Fe}_{2} \mathrm{O}_{3}$ in the chemical composition of a mold powder acts similar to $\mathrm{CaF}_{2}$, which can result in controlling the viscosity in the mold powder. Sample $\mathrm{H}$ (Figure 3) contains $3.3 \mathrm{wt} \%$ of $\mathrm{TiO}_{2}$ and 1.1 $\mathrm{wt} \%$ of $\mathrm{ZnO}$. This sample has much larger viscosity compared to the molten reference powder. Although $\mathrm{TiO}_{2}$ acted as an embryo maker in the chemical composition of the mold powder, there was no potent bond

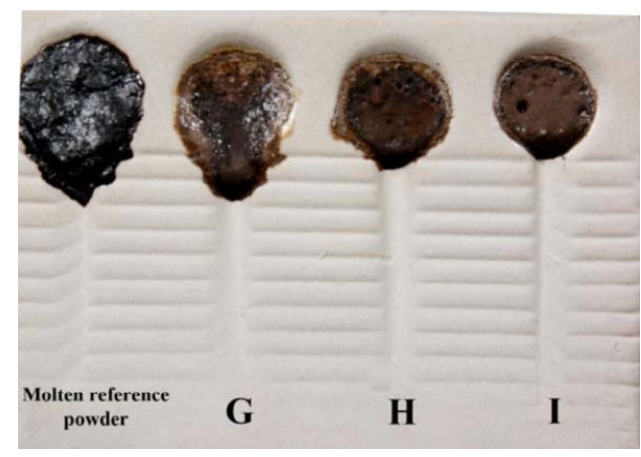

Figure 3. A schematic of the viscometer of molten samples $G, H$ and $I$ in comparison to the molten reference powder.

Table 6. Approximate surface area of samples $D, E, F$ and molten reference powder $\left(\mathrm{mm}^{2}\right)$.

\begin{tabular}{ccccc}
\hline Sample name & $\begin{array}{c}\text { Molten reference } \\
\text { powder }\end{array}$ & D & E & F \\
\hline $\begin{array}{c}\text { Approximate } \\
\text { surface area }\left(\mathrm{mm}^{2}\right)\end{array}$ & 723.002 & 967.155 & 983.564 & 584.646 \\
\hline
\end{tabular}


breaking compound such as $\mathrm{CaF}_{2}$ or $\mathrm{Fe}_{2} \mathrm{O}_{3}$ in the sample to decrease mold powder viscosity. In sample I (Figure 3), $\mathrm{Na}_{2} \mathrm{O}$ was increased from $9.08 \mathrm{wt} \%$ to $10.07 \mathrm{wt} \%$. Additionally, $3.33 \mathrm{wt} \%$ of $\mathrm{TiO}_{2}$ was added to the sample. This sample, too, has become completely viscous-no lubrication at all was obtained. It seems that the amount of the $\mathrm{Na}_{2} \mathrm{O}$ added through $\mathrm{Na}_{2} \mathrm{CO}_{3}$ was too little and that it should have been more to result in the expected lubrication. Figure 3 shows schematic of molten samples on groove viscometer. Besides the results of the analyses of samples $\mathrm{G}, \mathrm{H}$ and I done by image analysis software are given in Table 7.

As indicated in Table 7, sample G with an approximate surface area of $470.404 \mathrm{~mm}^{2}$ is comparable to the approximate surface area of the molten reference powder, i.e. $494.530 \mathrm{~mm}^{2}$. It can be concluded that samples $\mathrm{C}$ and $\mathrm{G}$ have similar viscosity to that of the molten reference powder.

\subsection{The Effect of Crystalline Behavior}

In order to evaluate the identification of reference powder as well as to study crystalline behavior of molten reference powder and samples $C$ and $G$, XRD analysis of the reference powder was conducted. Both XRD analysis and SEM images of the molten reference powder and sample $\mathrm{C}$ were conducted. Of sample $\mathrm{G}$, however, not only XRD analysis and SEM images, but also EDX analysis was conducted. The XRD analysis of reference powder revealed Wollastonite $\left(\mathrm{CaSiO}_{3}\right)$, Silica $\left(\mathrm{SiO}_{2}\right)$, Fluorine $\left(\mathrm{CaF}_{2}\right)$, Corundum $\left(\mathrm{Al}_{2} \mathrm{O}_{3}\right)$, Manganese Silicate $\left(\mathrm{MnSiO}_{3}\right)$, Sodium Carbonate $\left(\mathrm{Na}_{2} \mathrm{CO}_{3}\right), \mathrm{CaMg}\left(\mathrm{SiO}_{3}\right)_{2}$, $\mathrm{CaAl}_{2} \mathrm{O}_{4}$ phases. Taking into account the peak intensities in XRD analysis of this powder, the Wollastonite phase had the highest peak compared to other phases; in other words, Wollastonite constituted the main (basic) compound of that powder. Considering the XRD analysis of the reference powder, Wollastonite phase as index phase and finally chemical composition of Wollastonite, which is composed of $\mathrm{SiO}_{2}$ and $\mathrm{CaO}$, the choice of using Portland cement clinker as the main composition to prepare samples was an appropriate one. Figure 4 shows the XRD analysis of the reference powder.

The reference powder was molten upon viscometer groove in the temperature of $1150^{\circ} \mathrm{C}$. The XRD analysis of the molten reference powder showed such crystalline phases as Gehlentie $\left(\mathrm{Ca}_{2} \mathrm{Al}_{2} \mathrm{SiO}_{7}\right)$, Cuspidine $\left(\mathrm{Ca}_{4} \mathrm{~F}_{2} \mathrm{Si}_{2} \mathrm{O}_{7}\right)$, Akermanite $\left(\mathrm{Ca}_{2} \mathrm{MgSi}_{2} \mathrm{O}_{7}\right)$, Nepheline $\left(\mathrm{NaAlSiO}_{4}\right)$ and

Table 7. Approximate surface area of samples G, H, I and molten reference powder $\left(\mathrm{mm}^{2}\right)$.

\begin{tabular}{ccccc}
\hline Sample name & $\begin{array}{c}\text { Molten reference } \\
\text { powder }\end{array}$ & G & H & I \\
\hline $\begin{array}{c}\text { Approximate } \\
\text { surface area }\left(\mathrm{mm}^{2}\right)\end{array}$ & 494.530 & 470.404 & 362.153 & 283.793 \\
\hline
\end{tabular}

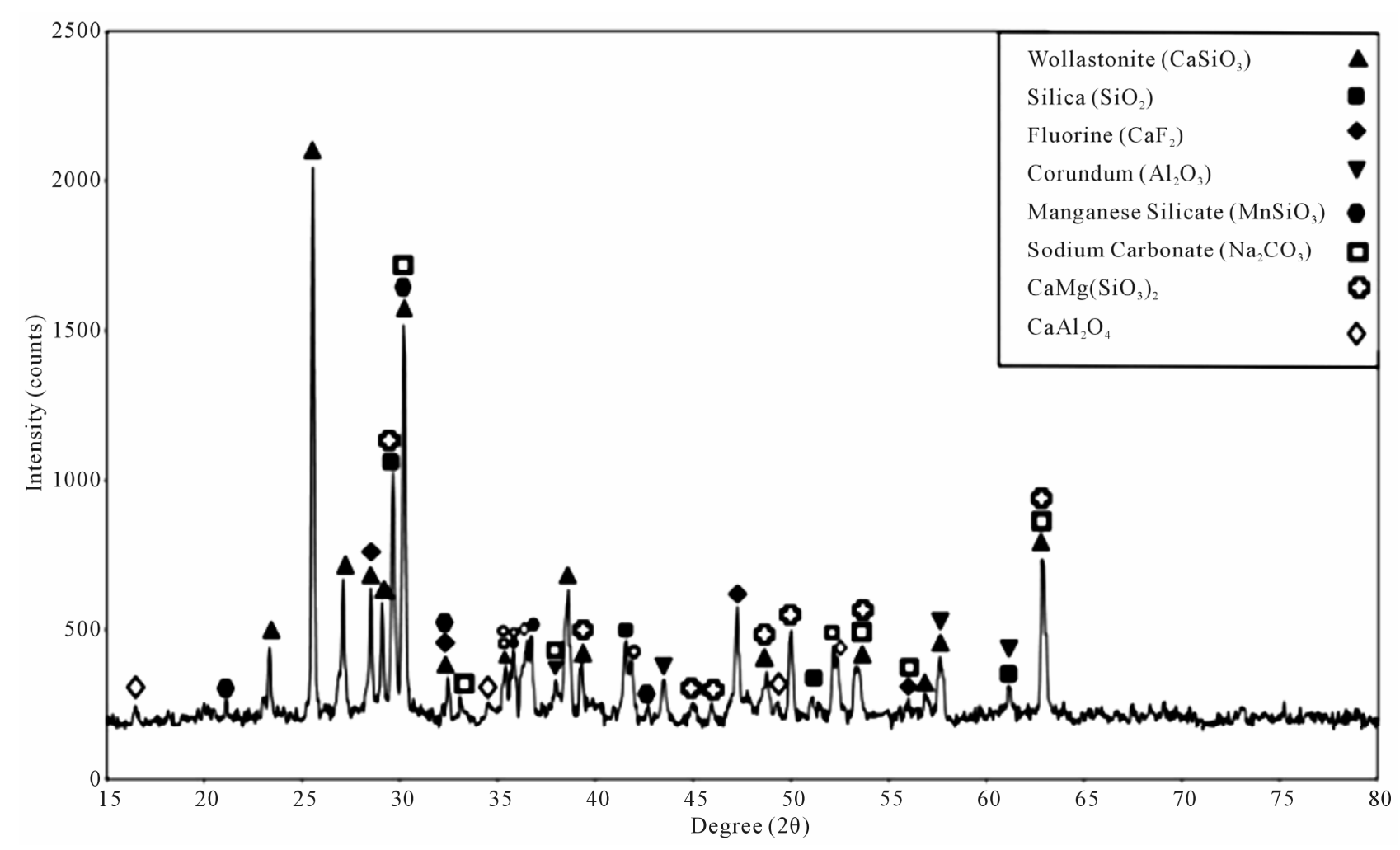

Figure 4. XRD analysis of reference powder. 
$\mathrm{Mn}_{3} \mathrm{O}_{4}$. In the reference powder, Wollastonite melted as the most main phase existing in the powder along with other materials such as Silica, Sodium Carbonate, Manganese Silicate, Fluorine, Corundum, $\mathrm{CaMg}\left(\mathrm{SiO}_{3}\right)_{2}$, and $\mathrm{CaAl}_{2} \mathrm{O}_{4}$. Such phases as Gehlenite, Cuspidine, Akerma- nite, Nepheline and $\mathrm{Mn}_{3} \mathrm{O}_{4}$ were obtained from the original melt upon the core solidification. Figure 5 shows the XRD analysis of the molten reference powder.

SEM images of the molten reference powder in Figure 6 reveal a wide matrix melt, which is a result of glass

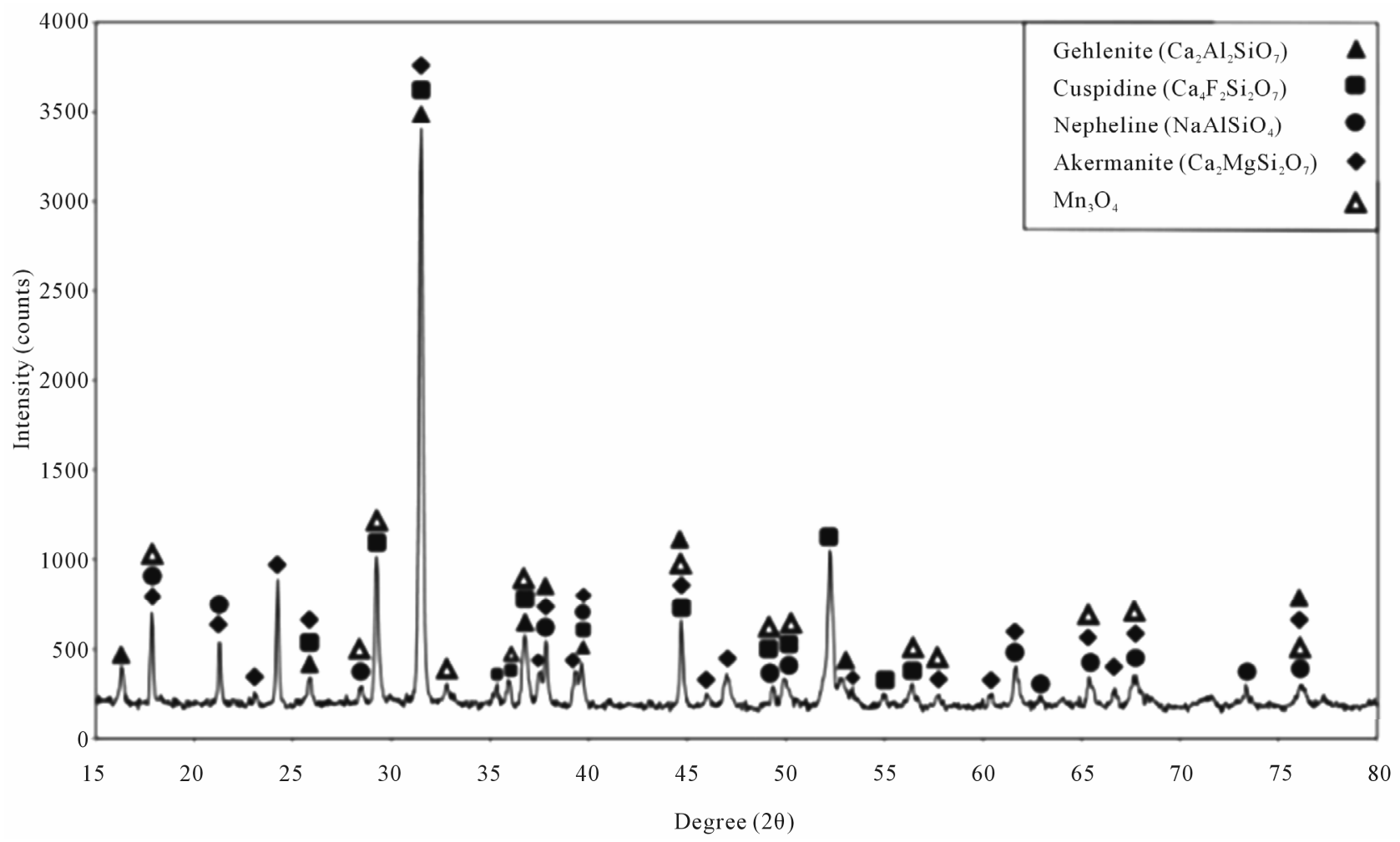

Figure 5. XRD analysis of the molten reference powder.

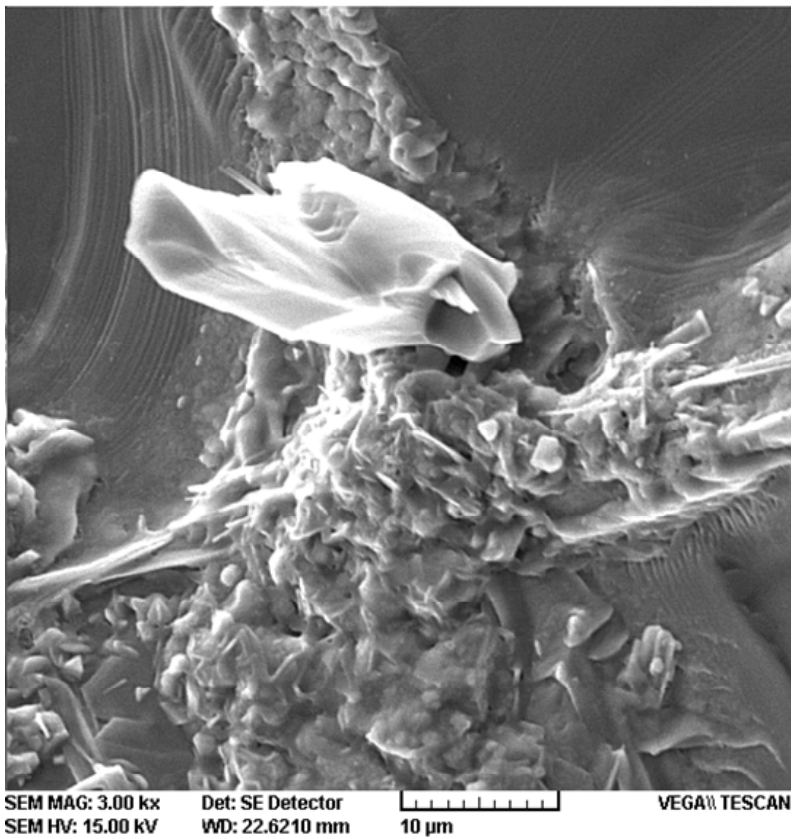

(a)

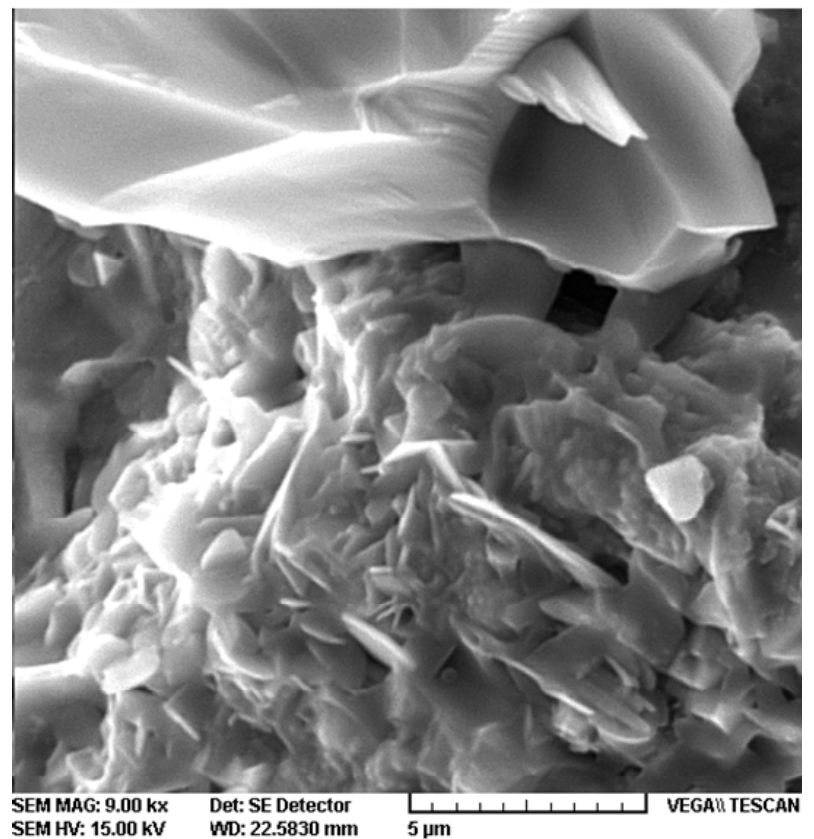

(b)

Figure 6. SEM images of the molten reference powder (a) 3000×; (b) $9000 \times$. 
making formation. Because of the glass being satiated with silica during the solidification, various crystals indicated in the matrix glass of SEM images of the molten reference powder have formed, which are especially important for the mold powder since they control its viscosity. They also decrease the extraordinarily low viscosity which may happen for the mold powder at the melt point of steel (i.e. $1600^{\circ} \mathrm{C}$ ) leading to a sudden fall of the over lubricant melt; thus, giving favorable viscosity to make suitable conditions for the ingot to cool off. The SEM images show the birth of those crystals (Figure 6).

Analysis of sample $\mathrm{C}$ shows the existence of Cuspidine, Gehlenite, Nepheline, Provskite $\left(\mathrm{CaTiO}_{3}\right)$, Akermanite, $\mathrm{Mn}_{3} \mathrm{O}_{4}$ and $\mathrm{Ca}_{3} \mathrm{SiO}_{5}$. In other words, XRD analysis of this sample denotes that the common 5 phases with the molten reference powder include: Gehlenite, Cuspidine, Akermanite, Nepheline and $\mathrm{Mn}_{3} \mathrm{O}_{4}$. Another phase for the sake of nucleation of $\mathrm{TiO}_{2}$ includes Provskite. A new phase is $\mathrm{Ca}_{3} \mathrm{SiO}_{5}$. In other words, by adding $\mathrm{TiO}_{2}$ to sample $C$, the phase Provskite was seen in its XRD analysis, which can form a crystalline sediment beside the phase Cuspidine and Perovskite leading to controlling the viscosity. $\mathrm{TiO}_{2}$ is a proper composition in the continuous casting mold powder of steel because it lowers viscosity and develops Provskite phase which has a similar role to Cuspidine. Data in Figure 7 shows the XRD analysis of sample C.
SEM images of this sample (Figure 8) showed crystals in the glass matrix, which control the viscosity of the mold powder, help reach the desired lubrication and optimize of continuous casting conditions.

Therefore, sample $\mathrm{C}$ appears to be a potential substitution for the reference mold powder applied in continuous casting of steel. The XRD analysis of sample G (Figure 9) showed the crystalline phases of Gehlenite, Akermanite, Nepheline and $\mathrm{Ca}_{3} \mathrm{SiO}_{5}$ along with $\mathrm{Mn}_{3} \mathrm{O}_{4}$.

In addition, by adding $\mathrm{Fe}_{2} \mathrm{O}_{3}$ and $\mathrm{TiO}_{2}$ this sample, the crystalline phases of Fayalite and Provskite were also obtained. Both seem to act in a similar way to the crystalline phase of Cuspidine in the composition of continuous casting of steel mold powders leading to controlling viscosity. The SEM images and EDX analysis of sample G (Figure 10 and Table 8) show fiber or strand shaped crystals in glass matrix, which directly influences the control of viscosity in this sample.

It appears that in this stage, the Provskite crystal $\left(\mathrm{CaTiO}_{3}\right)$ which is a cubic crystal replaces a single chain such as magnesium silicate $\left(\mathrm{MgSiO}_{3}\right)$ where the tetragonal $\mathrm{TiO}_{4}$ is considered in the place of $\mathrm{SiO}_{4}$ and is connected to adjacent tetragonals on both sides. This arrangement can be put all together as $(2 * 1)+(2 *(1 / 2))$; meaning that three oxygens belong to one $\mathrm{Ti}^{4+}$ and the $\mathrm{Ca}^{2+}$ is placed in the corner as an electron giving (similar to what is seen in asbestos). Of course, this is only a

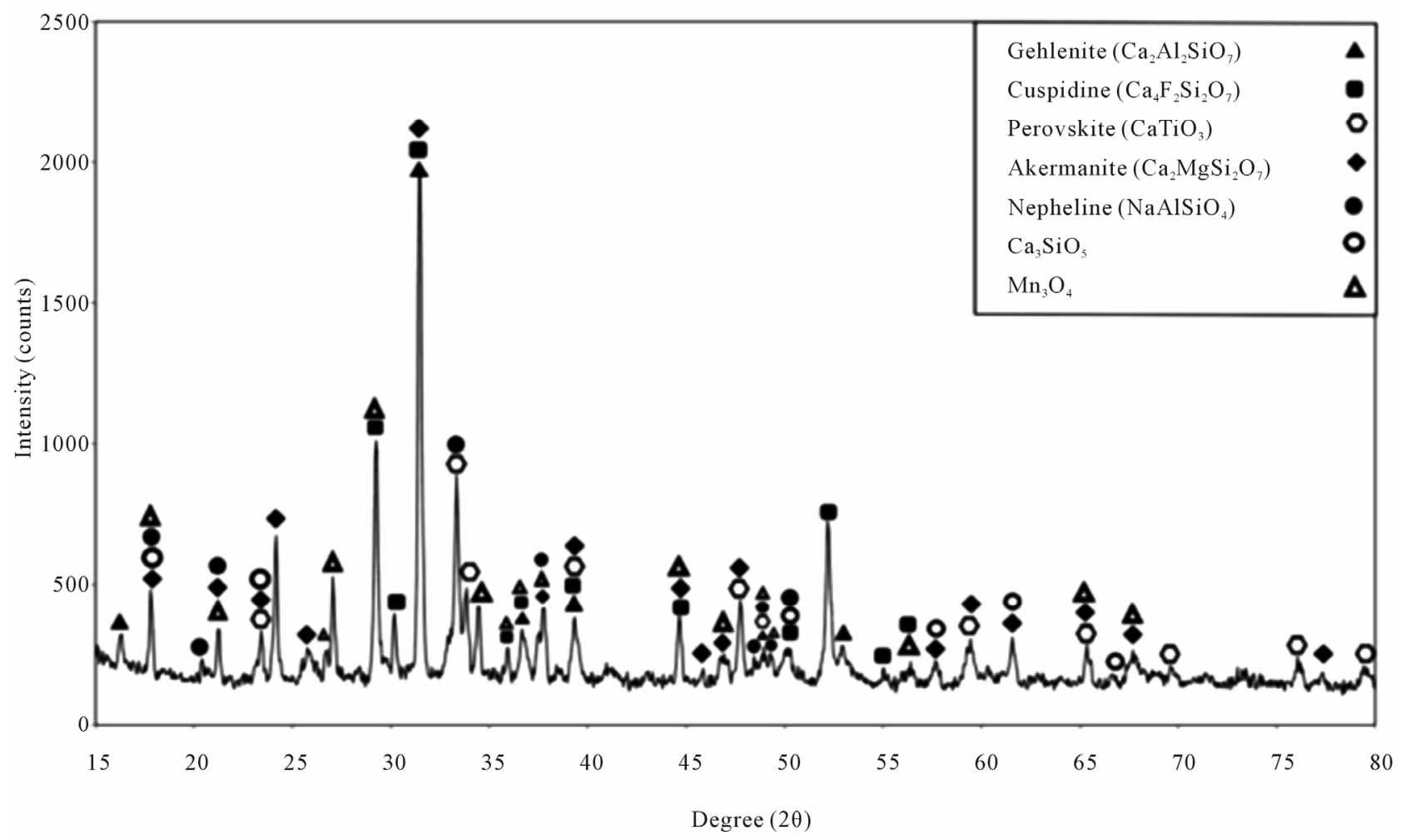

Figure 7. XRD analysis of sample C. 


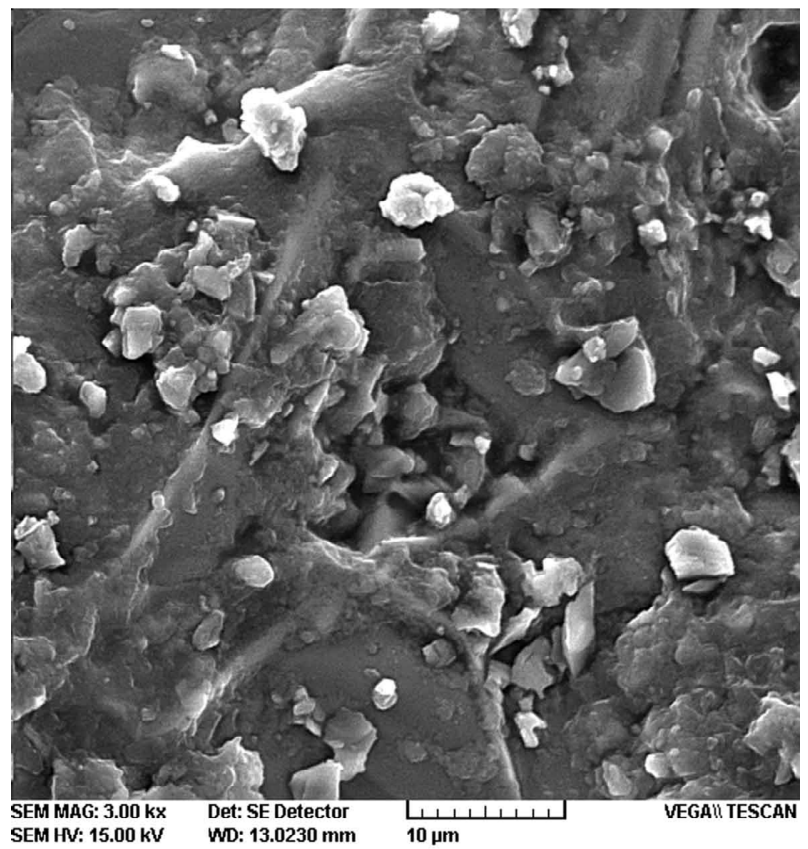

(a)

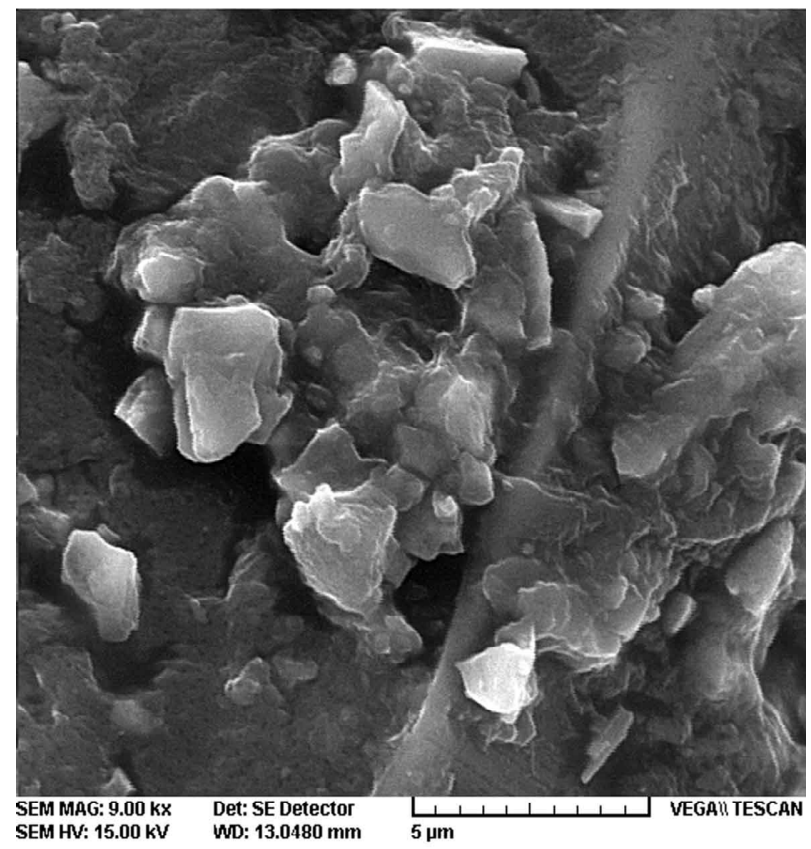

(b)

Figure 8. SEM images of sample C. (a) $3000 \times$; (b) $9000 \times$.

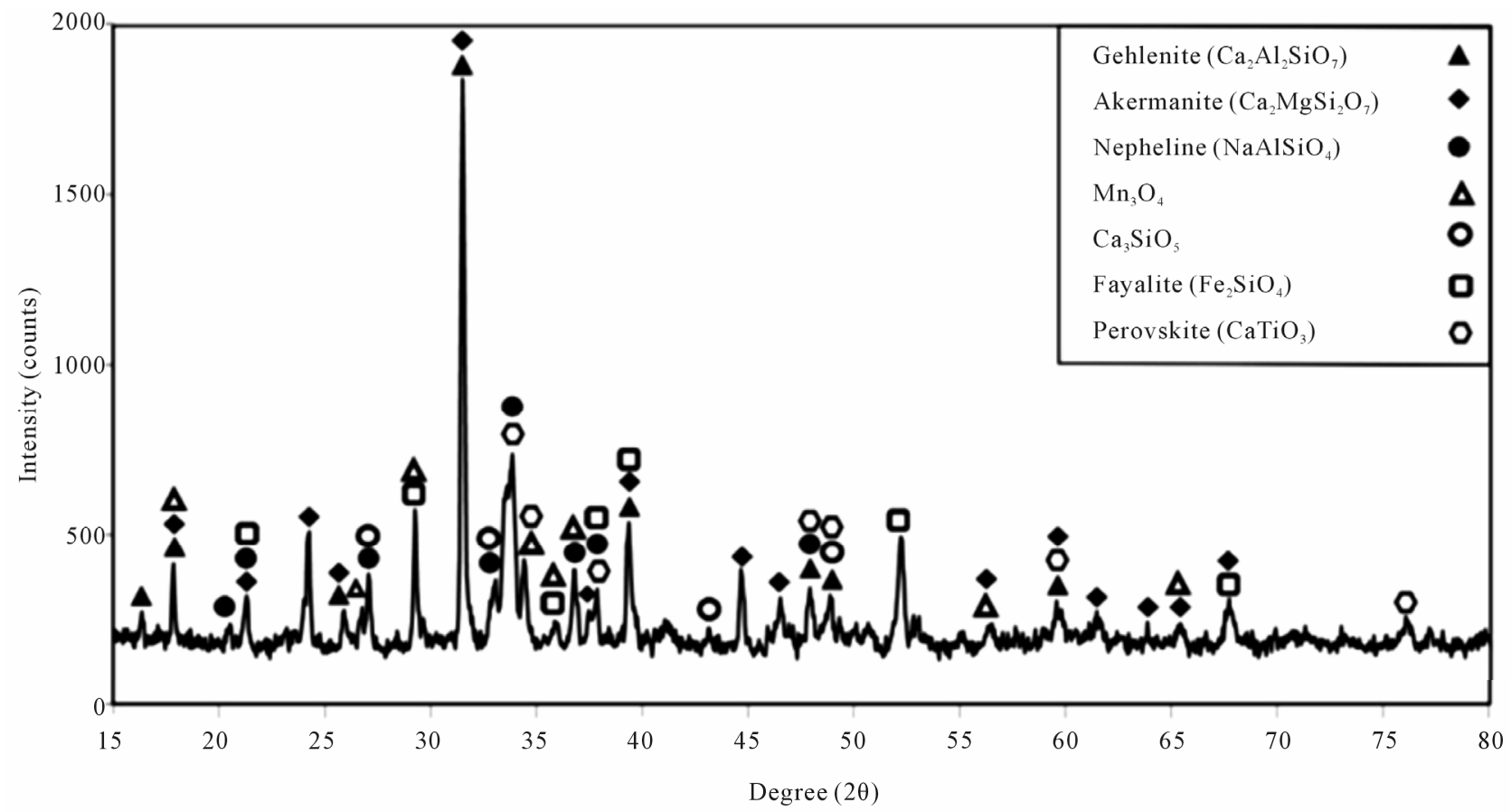

Figure 9. XRD analysis of sample G.

hypothesis at this stage and more research will be required to finalize it. The formation of $\mathrm{CaO}$. $\mathrm{TiO}_{2}$ as connected tetragonals as some of the existing cube shaped $\mathrm{CaTiO}_{3}$ is apparently not impossible as a rare allotropy, but it is not definite either. Results of EDX analysis of sample G (Figure 11 and Table 8) from white crystals of SEM images of sample $\mathrm{G}$ reported the presence of about $3.61 \mathrm{wt} \%$ of Ti element and $6.69 \mathrm{wt} \%$ of Fe element.
It seems that this matter showed formation of Provskite and Fayalite crystals, alongside other crystals such as Gehlenite, Akermanite, Nepheline, etc. in the glass matrix with the images of SEM. It can be concluded that formation of these crystals in the matrix of glass will result in controlling the viscosity of the mold powder, creation of desired lubrication and optimizing of continuous casting conditions. 


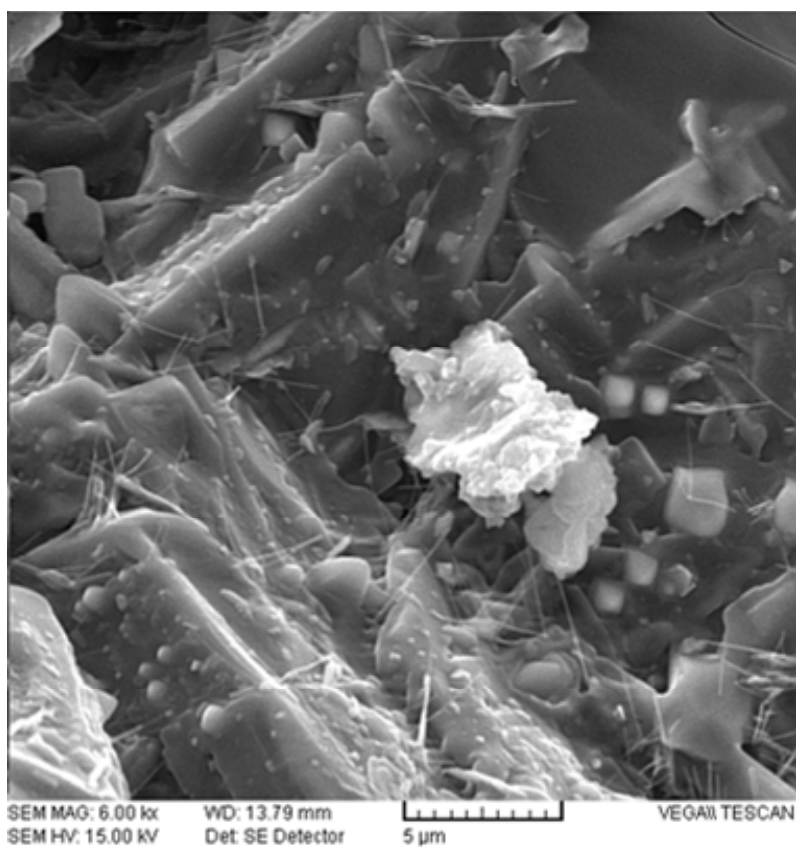

(a)

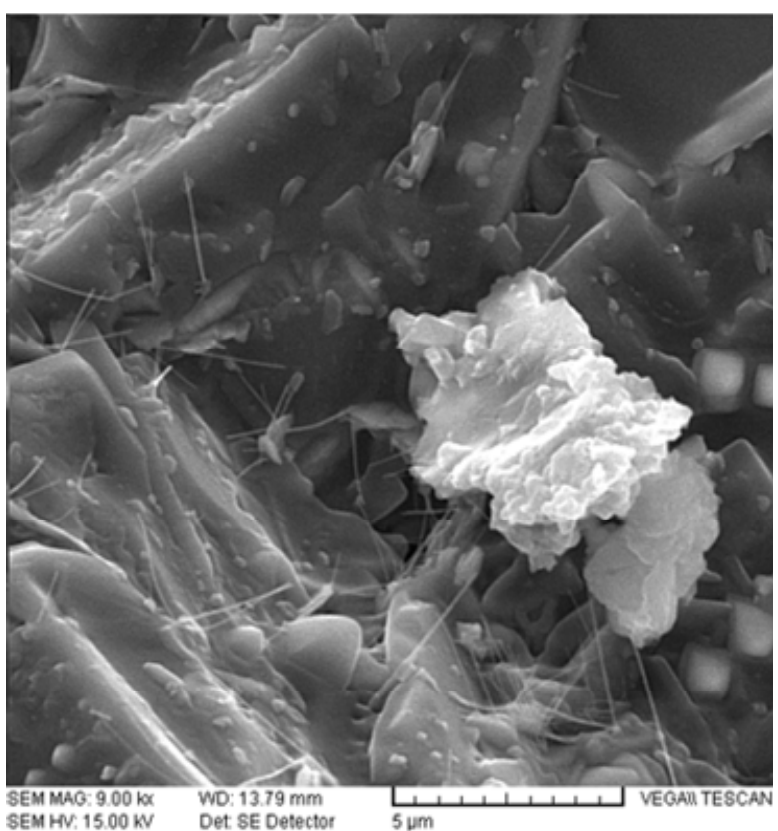

(b)

Figure 10. SEM images of sample G (a) $6000 \times$; (b) $9000 \times$.

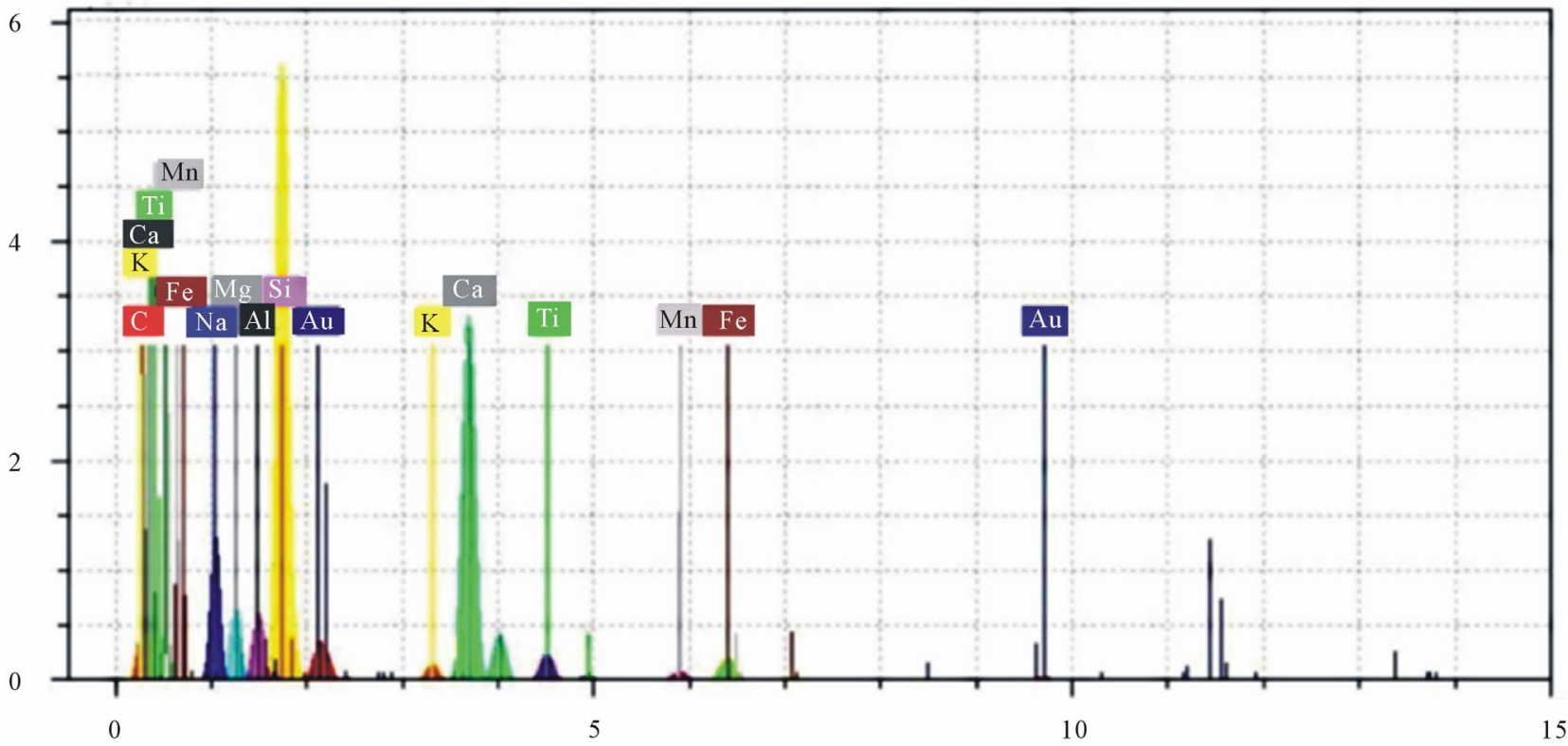

Figure 11. EDX analysis results of white crystals of SEM images of sample G.

\section{Conclusions}

1) Portland cement clinker, which is a very appropriate composition for steel continuous casting mold powders, was successfully used in the chemical compositions of the examined mold powders instead of Wollastonite.

2) $\mathrm{Li}_{2} \mathrm{O}$ has too much fluidity and therefore significantly decreases viscosity. Thus, it is not recommended to be used in the mold powder composition.
3) Using $\mathrm{B}_{2} \mathrm{O}_{3}$ in the mold powder composition decreases viscosity and increases fluidity. $\mathrm{B}_{2} \mathrm{O}_{3}$ is not recommended to be used in the mold powder composition. On the other hand, $\mathrm{B}_{2} \mathrm{O}_{3}$ is a potent lubricating one, which must be used in amounts of less than $2 \mathrm{wt} \%$ in the chemical composition of mold powders to obtain favorable lubrication.

4) $\mathrm{TiO}_{2}$ is a proper composition in the continuous casting mold powder of steel since it decreases viscosity 
Table 8. EDX analysis results of white particles of SEM images of sample $\mathbf{G}$.

\begin{tabular}{ccccc}
\hline Element & Series & $\begin{array}{c}\text { unn. C } \\
{[\mathrm{wt} \%]}\end{array}$ & $\begin{array}{c}\text { norm. C } \\
{[\mathrm{wt} \%]}\end{array}$ & $\begin{array}{c}\text { atom. C } \\
{[\mathrm{at} \%]}\end{array}$ \\
\hline Carbon & K series & 0.00 & 0.00 & 0.01 \\
Oxygen & K series & 10.49 & 12.39 & 22.24 \\
Sodium & K series & 8.26 & 9.76 & 12.19 \\
Magnesium & K series & 3.41 & 4.03 & 4.76 \\
Aluminum & K series & 2.81 & 3.32 & 3.54 \\
Silicon & K series & 22.57 & 26.66 & 27.27 \\
Potassium & K series & 1.02 & 1.21 & 0.89 \\
Calcium & K series & 25.96 & 30.65 & 21.98 \\
Titanium & K series & 3.06 & 3.61 & 2.17 \\
Manganese & K series & 1.42 & 1.68 & 0.88 \\
Iron & K series & 5.66 & 6.69 & 3.44 \\
\hline
\end{tabular}

and develops the phase of Perovskite which plays a similar role to that of the Cuspidine. Taking into account the XRD analysis of sample $\mathrm{C}$, the crystalline phase of Provskite functions in a similar way to Cuspidine, which results in the formation of a crystalline sediment in the solidified slag film.

5) Some compositions such as $\mathrm{ZnO}$ and $\mathrm{Na}_{2} \mathrm{O}$ have reciprocal effect upon mold powders' viscosity, which have appropriate potential for producing similar viscosity to that of the molten reference powder.

6) Through utilizing $\mathrm{TiO}_{2}$ in amounts of about $3 \mathrm{wt} \%$ and $3 \mathrm{wt} \%$ of $\mathrm{Fe}_{2} \mathrm{O}_{3}$ (surplus of existing $\mathrm{Fe}_{2} \mathrm{O}_{3}$ in the chemical composition of Portland cement clinker), one fluorine-free sample of mold powder was prepared, which obtained similar viscosity and crystallization to those of the molten reference powder. This is the fluorine-free sample that can be substituted with the reference powder utilized in steel continuous casting industry. However, it must be taken into consideration that this proposed fluorine-free sample is experimented regarding viscosity and crystallization.

\section{REFERENCES}

[1] E. T. Turkdogan, "Fundamentals of Steelmaking," Cambridge University Press, Cambridge, 1996, pp. 138-179.

[2] M. Mueller, W. Willenborg, K. Hilpert and L. Singheiser, "Structural Dependence of Alkali Oxide Activity in Coal Ash Slags," VII International Conference on Molten Slags, Fluxes and Salts, Cape Town, 25-25 January 2004.

[3] M. Nakamoto, J. Lee and T. Tanaka, "A Model for Estimation of Molten Silicate Slag," ISIJ International, 2005, Vol. 45, No. 5, 2005, pp. 651-656.

doi:10.2355/isijinternational.45.651
[4] S. Sridhar, "Estimation Models for Molten Slag and Alloy Viscosities," JOM Journal of the Minerals, Metals and Materials Society, Vol. 54, No. 11, 2005, pp. 46-48.

[5] R. F. Brooks, A. T. Dinsdale and P. N. Quested, "The Measurement of Viscosity of Alloys-A Review of Methods, Data and Models," Measurement Science and Technology, Vol. 16, No. 2, 2005, pp. 354-362. doi:10.1088/0957-0233/16/2/005

[6] Q. Shu and J. Zhang, "Viscosity Estimatin for Slags Containing Clacium Fluoride," Journal of University of Science and Technology Beijing, Vol. 12, No. 3, 2005, p. 221.

[7] P. V. Riboud and M. Larrecq, "Fundamental Study of the Behavior of Casting Powders, ISIJ International, Vol. 36, 1996, pp. 522-525.

[8] C. Orrling, A. W. Cramb, A. Tilliander and Y. Kashiwaya, "Observations of the Melting and Solidification Behavior of Mold Slags," Iron and Steelmaker, Vol. 27, No. 1, 2000, pp. 53-63.

[9] S. Feldbauer, I. Jimbo, A. Sharan, K. Shimizu, W. king, J. Stepanek, J. Harman and A. W. Cramb, "Physical Properties of Mold Slags That Are Relevant to Clean Steel Manufacture," Proceedings of 78th Steelmaking Conference, Nashville, 2-5 April 1995, pp. 655-667.

[10] K. C. Mills, S. Sridhar, A. S. Normanton and S. T. Mallaband, "Mould Flux Behavior in Continuous Casting," The Brimacombe Memorial Symposium, Vancouver, 1-4 October 2000, pp. 781-794.

[11] P. V. Riboud, Y. Roux, L. D. Lucas and H. Gaye, "Improvement of Continuous Casting Powders," Fachber Huttenprax Metallweiterverarb, Vol. 19, No. 10, 1981, pp. 859-869.

[12] G. Urbain, F. Cambier, M. Deletter and M. R. Anseau, "Viscosity of Silicate Melts," Transactions and Journal of British Ceramics Society, Vol. 80, No. 4, 1981, pp. 139-141.

[13] E. T. Turkdogan, "Physicochemical Properties of Molten Slags and Glasses," Metals Society, London, 1983, p. 11.

[14] S. Seetgraman, D. Sichen and F. Z. Ji, "Estimation of Viscosities of Ternary Silicate Melts Using the Excess Gibbs Energy of Mixing," Metallurgical and Materials Transaction B, Vol. 31, No. 1, 2000, pp. 105-109. doi:10.1007/s11663-000-0135-7

[15] L. Zhang and S. Jahanshahi, "Review and Modeling of Viscosity of Silicate Melts: Part I. Viscosity of Binary and Ternary Silicates Containing $\mathrm{CaO}, \mathrm{MgO}$ and $\mathrm{MnO}$," Metallurgical and Materials Transactions B, Vol. 29, No. 1, 1998, pp. 177-186.

[16] G. Wen, S. Sridhar, P. Tang, X. Qi and Y. Liu, "Development of Fluoride-Free Mold Powders for Peritectic Steel Slab Casting," ISIJ International, Vol. 47, No. 8, 2007, pp. 1117-1125. doi:10.2355/isijinternational.47.1117

[17] M. K. Koul, S. Sankaranarayanan, D. Apelian, W. L. McCauley, "Mould Powder Technology," Press of Northeast University of Technology, Shenyang, 1988, pp. 2-14.

[18] A. Morita, T. Omoto and Y. Iwamoto, "Molding Powder for Continuous Casting of Steel and a Method for Continuous Casting of Steel," US Patent No. 6461402, 2002. 